\title{
POTENSI EKSTRAK DAUN KEMANGI (Ocimum sanctum L.) SEBAGAI ANTIBAKTERI TERHADAP Staphylococcus aureus ATCC 25923
}

\author{
Nur'Aini Purnamaningsih', Francisca Romana Sri Supadmi ${ }^{2}$ \\ Universitas Jenderal Achmad Yani Yogyakarta ${ }^{12}$ \\ e-mail: ${ }^{1}$ nurainipurnamaningsih21@gmail.com, ${ }^{2}$ siskatbd.ayani@gmail.com
}

\begin{abstract}
Antibacterial compounds are compounds that can inhibit bacterial growth. The components contained in the basil leaf extract have the potential to be developed as a source of antibacterial active ingredients. Basil leaves are a plant that has antibacterial potential. This study aims to test the antibacterial activity of the basil leaf extract (Ocimum sanctum L.) with various concentrations of 20\%, 40\%, 60\%, 80\%, and $100 \%$ against Staphylococcus aureus ATCC 25923. Antibacterial activity test using the well diffusion method. The results showed that basil leaf extract (Ocimum sanctum L.) concentrations of 20\%, 40\%, 60\%, 80\%, and $100 \%$ could inhibit the growth of Staphylococcus aureus ATCC 25923. The concentration of basil leaf extract was $100 \%$ effective as an antibacterial against Staphylococcus aureus bacteria. ATCC 25923 of $12.60 \mathrm{~mm}$.
\end{abstract}

Keywords: kemangi; antibacterial;Staphylococcus aureus

\begin{abstract}
ABSTRAK
Senyawa antibakteri merupakan senyawa yang dapat menghambat pertumbuhan bakteri. Komponen yang terkandung dalam ekstrak daun kemangi potensial untuk dikembangkan sebagai sumber bahan aktif antibakteri.Daun kemangi merupakan salah satu tanaman yang memiliki potensi sebagai antibakteri. Penelitian ini bertujuan untuk menguji aktivitas antibakteri dari ekstrak daun kemangi (Ocimum sanctum L.) dengan variasi konsentrasi $20 \%, 40 \%, 60 \%, 80 \%$, dan $100 \%$ terhadap Staphylococcus aureus ATCC 25923. Uji aktivitas antibakteri dengan menggunakan metode difusi sumuran. Hasil penelitian menunjukkan bahwa ekstrak daun kemangi (Ocimum sanctum L.) konsentrasi 20\%, 40\%, 60\%, 80\%, dan $100 \%$ dapat menghambat pertumbuhan Staphylococcus aureus ATCC 25923. Konsentrasi ekstrak daun kemangi $100 \%$ efektif sebagai antibakteri terhadap bakteri Staphylococcus aureus ATCC 25923sebesar $12,60 \mathrm{~mm}$.
\end{abstract}

Kata kunci: kemangi, antibakteri, Staphylococcus aureus

\section{PENDAHULUAN}

Indonesia merupakan negara tropis yang kaya akan berbagai jenis tumbuhan yang berpotensi dimanfaatkan di bidang kesehatan. Banyak tanaman yang dapat menghasilkan metabolit sekunder berupa bahan antibakteri ${ }^{(1)}$. Senyawa antibakteri merupakan senyawa yang dapat menghambat pertumbuhan bakteri. Komponen yang terkandung dalam ekstrak daun kemangi potensial untuk dikembangkan sebagai sumber bahan aktif antibakteri.

Berdasarkan sifat toksisitasnya, antibakteri dapat bersifat membunuh bakteri (bakterisidal) dan menghambat pertumbuhan bakteri (bakteriostatik) ${ }^{(5)}$. Mekanisme kerja antibakteri dapat melalui berbagai cara, diantaranya menghambat sintesis dinding sel, menghamba protein dinding sel, menghambat sintesis asam nukleat, dan menghambat metabolisme sel mikroba.

Kemangi adalah tanaman yang mudah didapatkan yang tersebar hampir di seluruh Indonesia karena dapat tumbuh liar maupun dibudidayakan ${ }^{(6)}$. Daun kemangi (Ocimum sanctum L.) merupakan salah satu tanaman yang memiliki potensi sebagai antibakteri. Daun kemangi mengandung senyawa metabolit antara lain flavonoid, tanin, steroid, dan saponin $^{(2)}$. Kandungan daun kemangi yang bersifat antibakteri adalah minyak atsiri. Minyak atsiri daun kemangi memiliki konsentrasi bunuh minimal (KBM) $0,5 \%$ terhadap bakteri $S$. aureus, $0,25 \%$ terhadap bakteri E.coli, $2 \%$ terhadap bakteri $S$. epidermidis $^{(7)}$.

Penelitian Nurmashita (2015) melaporkan bahawa pasta gigi ekstrak daun kemangi yang mengandung abrasif di berbagai konsentrasi $(37,42$ 
dan $47 \%$ ) menghasilkan zona hambat terhadap pertumbuhan bakteri $S$. mutans dengan diameter penghambatan 1,241- 4,028 $\mathrm{mm}^{(8)}$.

Penelitian Ali dan Savita (2012) melaporkan bahwa kandungan flavonoid daunkemangi dapat memberikan efek antibakteri terhadap E. coli, $S$. aureus dan K. pneumonia. Penelitian tersebut juga menunjukkan bahwa kombinasi dari kedua senyawa flavonoid daun kemangi yaitu orientin dan visenin memberikan efek antibakteri yang sinergis dibandingkan dengan penggunaan salah satu dari kedua senyawa flavonoid tersebut ${ }^{(9)}$.

Oleh karena itu, dalam penelitian ini dilakukan penelitian mengenai uji antibakteri ekstrak daun kemangi (Ocimum sanctum L.) dengan variasi konsentrasi 20\%, 40\%, 60\%, 80\%, dan $100 \%$ terhadap Staphylococcus aureus ATCC 25923.

\section{METODE}

Alat

Alat yang digunakan dalam penelitian ini yaitu timbangan analitik, oven, autoclave, Laminar Air Flow, waterbath, shaker, inkubator, petridish, pinset, botol vial, bunsen, hot plate, magnetic stirrer, palu sumuran, jangka sorong, mikropipet, tip pipet, erlenmeyer, dan Mc. Farland Standart.

\section{Bahan}

Ekstrak kemangi, bakteri Staphylococcus aureus diperoleh dari Balai Laboratorium Kesehatan Yogyakarta. Media yang digunakan meliputi Nutrient Agar untuk peremajaan bakteri uji, media Muller Hinton Agar untuk uji aktivitas antibakteri. Bahan lainnya meliputi alkohol 70\%, chlorampenicol, aquadest, swab steril, dan paperdisk.

Alat

Alat yang digunakan dalam penelitian ini yaitu timbangan analitik, oven, autoclave, Laminar Air Flow, waterbath, shaker, inkubator, petridish, pinset, botol vial, bunsen, hot plate, magnetic stirrer, palu sumuran, jangka sorong, mikropipet, tip pipet, erlenmeyer, dan Mc. Farland Standart.

\section{Prosedur \\ Pembuatan Media}

Media yang digunakan untuk peremajaan bakteri uji adalah Nutrient Agar (NA), sedangkan media yang digunakan untuk uji aktivitas antibakteri adalah Muller Hinton Agar (MHA).
Media NA sebanyak 28 gram dilarutkan ke dalam 1 liter aquadest, kemudian dipanaskan dengan hot plate dan diaduk dengan magnetic stirrer. Setelah itu disterilkan dengan autoclave dengan suhu $121^{\circ} \mathrm{C}$, tekanan 1 atm, selama 15 menit.

Media MHA sebanyak 13 gram dilarutkan ke dalam 1 liter aquadest, kemudian dipanaskan dengan hot plate dan diaduk dengan magnetic stirrer. Setelah itu disterilkan dengan autoclave dengan suhu $121^{\circ} \mathrm{C}$, tekanan 1 atm, selama 15 menit.

\section{Penyiapan Bakteri Uji}

Bakteri uji diremajakan kembali dan diinokulasikan secara aseptik ke dalam media NA, lalu diinkubasi pada suhu $37^{\circ} \mathrm{C}$ selama 24 jam. Sebelum digunakan untuk uji aktivitas antibakteri, bakteri uji dilakukan pengenceran terlebih dahulu dengan larutan $\mathrm{NaCl}$ fisiologis, kemudian dihomogenkan dengan vortex stirrer. Setelah dihomogenkan, kekeruhan suspensi bakteri dibandingkan dengan larutan Mc. Farland Standart dengan tingkat kepadatan $10^{8} \mathrm{CFU}$.

\section{Uji Aktivitas Antibakteri Ekstrak Uji}

Ekstrak daun kemangi dibuat variasi konsentrasi 20\%, 40\%, 60\%, dan $80 \%$. Uji aktivitas antibakteri dengan menggunakan metode difusi sumuran. Difusi sumuran adalah pembuatan lubang pada media padat yang telah diinokulasi bakteri. Lubang tersebut diinjeksikan dengan ekstrak yang diujikan. Parameter dari metode ini adalah dengan mengukur zona hambat yang terbentuk di sekeliling sumuran.

Suspensi bakteri uji diinokulasikan ke atas media Muller Hinton Agar plate, kemudian dibuat lubang sumuran. Pada masing-masing petridish dibuat lubang sumuran dengan diameter $6 \mathrm{~mm}$, kemudian $50 \mu \mathrm{m}$ ekstrak dari masing-masing konsentrasi diinjeksikan ke lubang sumuran tersebut. Kontrol negatif menggunakan aquadest steril, sedangkan kontrol positif yang digunakan adalah kloramfenikol. Kemudian diinkubasi pada suhu $37^{\circ} \mathrm{C}$ selama 24 jam. Selanjutnya diameter zona hambat yang terbentuk diamati dan diukur menggunakan jangka sorong. 
HASIL

Daun kemangi merupakan salah satu tanaman yang memiliki potensi sebagai antibakteri. Hasil identifikasi spesies daun kemangi yang digunakan dalam penelitian ini:

$\begin{array}{ll}\text { Kingdom } & \text { : Plantae } \\ \text { Divisio } & \text { : Tracheophyta } \\ \text { Class } & \text { : Magnoliopsida } \\ \text { Ordo } & \text { : Lamiales } \\ \text { Familia } & \text { : Lamiaceae } \\ \text { Genus } & \text { : Ocimum } \\ \text { Spesies } & \text { : Ocimum sanctum } \text { L. } \\ \text { Sinonim } & : \text { - } \\ \text { Nama lokal } & \text { : Kemangi }\end{array}$

Untuk menguji aktivitas antibakteri dari ekstrak daun kemangi (Ocimum sanctum L.), maka dilakukan serangkaian uji daya hambat ekstrak daun kemangi (Ocimum sanctum L.) dengan variasi konsentrasi $20 \%, 40 \%, 60 \%, 80 \%$, dan $100 \%$ menggunakan metode difusi sumuran terhadap bakteri patogen, yaitu Staphylococcus aureus ATCC 25923.

Hasil penelitian menunjukkan bahwa ekstrak daun kemangi (Ocimum sanctum L.) dapat menghambat pertumbuhan kedua bakteri yang diujikan. Zona hambat bakteri yang terbentuk oleh Staphylococcus aureus ATCC 25923 ditunjukkan pada Gambar 1.

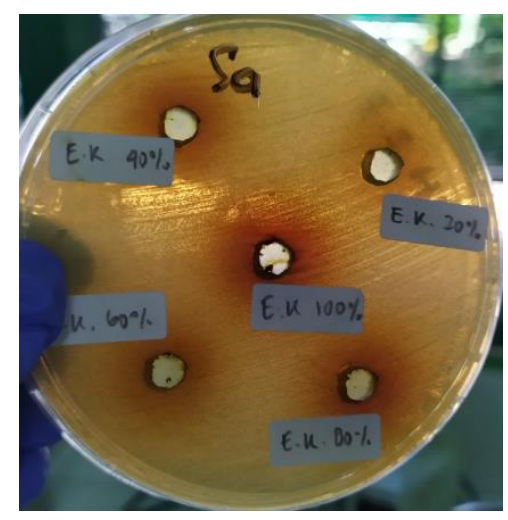

Gambar 1. Aktivitas antibakteri ekstrak kemangi terhadap Staphylococcus aureus ATCC 25923

Aktivitas penghambatan terhadap bakteri diukur berdasarkan diameter zona hambat yang terbentuk. Hasil pengukuran diameter zona hambat terhadap bakteri Staphylococcus aureus ATCC 25923ditunjukkan pada Tabel 1.
Tabel 1. Diameter Zona Hambat Ekstrak Daun Kemangi (Ocimum sanctum L.) terhadap Staphylococcus aureus ATCC 25923

\begin{tabular}{clccccc}
\hline \multirow{2}{*}{ No. } & Sampel & & \multicolumn{4}{c}{ Diameter Zona Hambat (mm) } \\
\cline { 3 - 7 } & & 1 & 2 & 3 & $\begin{array}{c}\text { Rata- } \\
\text { rata }\end{array}$ \\
\hline 1. & $\begin{array}{l}\text { Ekstrak daun } \\
\text { kemangi }\end{array}$ & $20 \%$ & 6 & 6 & 6 & 6 \\
\hline & & $40 \%$ & 6,60 & 6,60 & 6,85 & 6,68 \\
\hline & $60 \%$ & 8,10 & 8,30 & 8,10 & 8,17 \\
\hline & $80 \%$ & 9,60 & 9,90 & 9,90 & 9,80 \\
\hline & $100 \%$ & $\begin{array}{c}12,6 \\
0\end{array}$ & $\begin{array}{c}12,4 \\
0\end{array}$ & $\begin{array}{c}13,9 \\
5\end{array}$ & 12,60 \\
\hline 2. & $\begin{array}{l}\text { Kontrol + } \\
\text { (kloramfenikol) }\end{array}$ & & 30 & 33 & 32 & 31,67 \\
\hline 3. & $\begin{array}{l}\text { Kontrol - } \\
\text { (aquadest) }\end{array}$ & 0 & 0 & 0 & 0 \\
\hline & & & & & \\
\hline
\end{tabular}

\section{PEMBAHASAN}

Ekstrak daun kemangi (Ocimum sanctum L.) menunjukkan aktivitas antibakteri terhadap Staphylococcus aureus ATCC 2592. Daun kemangi (Ocimum sanctum L.) merupakan salah satu tanaman yang memiliki potensi sebagai antibakteri. Daun kemangi mengandung senyawa metabolit antara lain flavonoid, tanin, steroid, dan saponin ${ }^{2}$. Golongan flavonoid yang terkandung di dalam ekstrak daunkemangi (Ocimum sanctum L.) dapat merusak dinding sel bakteri sehingga komponen utama dari sel keluar dan menyebabkan kematian sel bakteri, serta menghambat pembentukan protein sel. Tanin berperan dalam merusak membran sel dan alkaloid berperan dalam denaturasi protein ${ }^{(11)}$.

Tabel 1 menunjukkan bahwa ekstrak daun kemangi (Ocimum sanctum L.) dengan variasi konsentrasi $20 \%, 40 \%, 60 \%, 80 \%$ dan $100 \%$ mempunyai aktivitas antibakteri terhadap Staphylococcus aureus ATCC 25923. Konsentrasi ekstrak daun kemangi $100 \%$ efektif sebagai antibakteri terhadap bakteri Staphylococcus aureus ATCC 25923sebesar 12,60 mm. Semakin tinggi konsentrasi ekstrak, maka cenderung semakin tinggi diameter zona hambatnya. Semakin tinggi konsentrasi suatu bahan antibakteri, maka aktivitas antibakterinya akan semakin kuat ${ }^{(11)}$.

Ekstrak daun kemangi (Ocimum sanctum L.) menunjukkan aktivitas antibakteri terhadap Staphylococcus aureus ATCC 2592. Daun kemangi (Ocimum sanctum L.) merupakan salah satu tanaman yang memiliki potensi sebagai antibakteri. Daun kemangi mengandung senyawa metabolit antara lain flavonoid, tanin, steroid, dan saponin ${ }^{2}$. Golongan flavonoid yang terkandung di dalam ekstrak daun kemangi (Ocimum sanctum L.) dapat merusak dinding sel bakteri sehingga komponen utama dari sel keluar dan menyebabkan kematian sel bakteri, serta menghambat pembentukan protein sel. Tanin berperan 
dalam merusak membran sel dan alkaloid berperan dalam denaturasi protein ${ }^{(12)}$.

Staphylococcus aureus ATCC 25923 merupakan bakteri Gram positif.Perbedaan struktur dinding sel bakteri Gram positif dan Gram negatif mempengaruhi sensitivitas terhadap antibakteri. Dinding sel bakteri Gram positif terdiri atas sekitar 40 lapisan peptidoglikan, sehingga peptidoglikan mencapai $70 \%$ dari masa kering dinding sel menyebabkan dinding sel menjadi tebal dan kaku. Sedangkan bakteri Gram negatif memiliki dinding sel peptidoglikan hanya sekitar $10 \%$ dari masa kering dinding sel, sehingga menyebabkan dinding selnya lebih tipis ${ }^{(11)}$. Bakteri Gram negatif mempunyai kandungan lipid yang banyak serta memiliki protein porin yang berperan sebagai saluran masuknya zat aktif ke dalam sel bakteri. Masuknya zat aktif ini merusak aktivitas enzim dalam sel dan menyebabkan kerusakan sel. Kadar lipid yang tinggi di dalam sel akan meningkatkan permeabilitas zat aktif ke dalam sel.

\section{KESIMPULAN}

Ekstrak daun kemangi dengan variasi konsentrasi 20\%, 40\%, 60\%, 80\% dan $100 \%$ mempunyai aktivitas antibakteri terhadap Staphylococcus aureus ATCC 25923. Konsentrasi ekstrak daun kemangi $100 \%$ efektif sebagai antibakteri terhadap bakteri Staphylococcus aureus ATCC 25923 sebesar 12,60 mm.

\section{DAFTAR PUSTAKA}

1. Carson, C. F., Brian, J. M., dan Riley, T. V.2002. Mechanism of action of teatree oil on Staphylococcus aureusdetermined by time-kill, lyses, leakage,and salt tolerance assays and electronmicroscopy. Antimicrobial Agent andChemotherapy 6:1914-1920.

2. Ardiana, D. Y., Martha, P., Teuku, N., Puji, A. 2013. Formulasi Mouthwash Minyak Atsiri Daun Kemangi (OcimumbasilicumL.) Serta Uji Antibakteri Dan Antibiofilm Terhadap Bakteri Streptococcus mutans Secara In Vitro. Traditional Medicine Journal, Vol 18 No 2.

3. Dewi, I.K dan Yuanianto, B. 2016. Uji Efektifitas Sediaan Hand Sanitizer Kombinasi Ekstrak Daun Kemangi (Ocimum sanctum L.) dan Ekstrak Kulit Jeruk Purut (Cytrus hystrix). Jurnal Kebidanan dan Kesehatan Tradisional, Vol 1 (2): 100-144

4. Widyaningrum, N., Fudholi, A., Sudarsono, Setyowati, E.P. 2015. Buffer and emusifier optimization in cream with its antibacterial activity and sensitivity. Int. J. of Pharm. Sci. and Research, 6(12):1000-1006.
5. Iswandana, R dan Sihombing L.K.M. 2017. Formulasi, Uji Stabilitas Fisik, dan Uji Aktivitas Secara in Vitro Sediaan Spray Antibau Kaki yang Mengandung Ekstrak Etanol Daun Sirih (Piper betle L.). Pharmaceutical Science and Research. Vol 4 (3):121-131

6. Sudarsono. 2002. Tumbuhan Obat II (Hasil Penelitian, Sifat-Sifat dan Penggunaannya). Yogyakarta: Pusat Studi Obat Tradisional Universitas Gadjah Mada

7. Maryati, Fauzia, R.S, dan Rahayu T. 2007. Uji Aktivitas Antibakteri Minyak Atsiri Daun Kemangi terhadap A. aureus dan E.coli. Surakarta: Universitas Muhammadiyah Surakarta.

8. Nurmashita, D., Rijai, L., dan Sulistiarini, R. 2015. Pengaruh Penambahan Ekstrak Daun Kemangi (Ocimum basilicum L.) terhadap AKtivitas Antibakteri Basis Pasta Gigi. Jurnal Sains dan Kesehatan. Vol 1 (4): 159-167

9. Ali, H. dan Savita, D. 2012. In Vitro Antimicrobial Activity of Flavonoids of Ocimum sanctum with Synergistic Effect of tHeir Combined Form. Asian Pacific Journal of Topical Disease.

10. Salem, M., Nazir, M., Ali, M.S., Hussain,H., Lee, Y.S., Riaz, N., et al. (2010).Antimicrobial natural products:An update on future antibiotic drugcandidates. Natural Products Report,27, 238-254.Oktaviani, M., Fadhli, H. dan Yuneistya, E. (2019). Uji Aktivitas Antimikroba Ekstrak Etanol dari Kulit Bawang Merah (Allium cepa L.) dengan Metode Difusi Cakram. Pharmaceutical Science and Research. Vol 6 (1): 62-6

11. Pelczar, M. J. dan Chan, E. C. S., 1988, DasarDasar Mikrobiologi, diterjemahkan oleh Hadioetomo, R. S., Penerbit Universitas Indonesia, Jakarta

12. Adila, R., et al. 2013. Uji Antimikroba Curcuma spp. Terhadap Pertumbuhan Candida albicans, Staphylococcus aureus dan Escherichia coli. Jurnal Biologi Universitas Andalas (J. Bio. UA.). Vol : 3 No :1 